\title{
Intramuscular preadipocytes impede differentiation and promote lipid deposition of muscle satellite cells in chickens
}

Liping Guo ${ }^{1,2,3+}$, Huanxian Cui ${ }^{1,3+}$, Guiping Zhao ${ }^{1,3}$, Ranran Liu' ${ }^{1,3}$, Qinghe Li $i^{1,3}$, Maiqing Zheng ${ }^{1,3}$, Yuming $\mathrm{GuO}^{2,3^{*}}$ and Jie Wen ${ }^{1,3^{*}}$ (D)

\begin{abstract}
Background: Skeletal muscle satellite cells (MSC) are crucial for postnatal growth and regeneration of skeletal muscle. An interaction exists between MSC and intramuscular preadipocytes (IMPA). This study is the first to investigate the effects of IMPA on MSC in chickens and unveil the molecular mechanisms by transcriptome analysis.

Results: Primary MSC and IMPA were isolated from the pectoralis major muscle of 7-day-old chickens. After both cell types reached confluence, MSC were cultured alone or co-cultured with IMPA for 2 or $4 \mathrm{~d}$. MSC treated for $2 \mathrm{~d}$ were subjected to RNA-seq. A total of 1653 known differentially expressed genes (DEG) were identified between co-cultured and mono-cultured MSC ( $|\log 2 F C| \geq 1, F D R<0.01)$. Based on Gene Ontology analysis, 48 DEG related to muscle development were screened, including the key genes MYOD1, MYOG, PAX7, and TMEM8C. The 44 DEG related to lipid deposition included the key genes CD36, FABP4, ACSBG2, CYP7A1 and PLIN2. Most of the DEG related to muscle development were downregulated in co-cultured MSC, and DEG related to lipid deposition were upregulated. Immunofluorescence of MHC supported IMPA impeding differentiation of MSC, and Oil Red O staining showed concurrent promotion of lipid deposition. Pathway analysis found that several key genes were enriched in JNK/MAPK and PPAR signaling, which may be the key pathways regulating differentiation and lipid deposition in MSC. Additionally, pathways related to cell junctions may also contribute to the effect of IMPA on MSC.

Conclusions: The present study showed that IMPA impeded differentiation of MSC while promoting their lipid deposition. Pathway analysis indicated that IMPA might inhibit differentiation via the JNK/MAPK pathway, and promote lipid deposition via the PPAR pathway. This study supplies insights into the effect of IMPA on MSC, providing new clues on exposing the molecular mechanisms underlying the interplay between skeletal muscle and intramuscular fat in chickens.
\end{abstract}

Keywords: Muscle satellite cells, Intramuscular preadipocytes, Interaction, Myogenic differentiation, Lipid deposition, Chicken

\footnotetext{
* Correspondence: guoyum@cau.edu.cn; wenjie@caas.cn

${ }^{\dagger}$ Liping Guo and Huanxian Cui contributed equally to this work.

${ }^{2}$ College of Animal Science and Technology, China Agricultural University,

Beijing 100193, China

${ }^{1}$ Institute of Animal Sciences, Chinese Academy of Agricultural Sciences,

Beijing 100193, China

Full list of author information is available at the end of the article
}

(c) The Author(s). 2018 Open Access This article is distributed under the terms of the Creative Commons Attribution 4.0 International License (http://creativecommons.org/licenses/by/4.0/), which permits unrestricted use, distribution, and reproduction in any medium, provided you give appropriate credit to the original author(s) and the source, provide a link to the Creative Commons license, and indicate if changes were made. The Creative Commons Public Domain Dedication waiver (http://creativecommons.org/publicdomain/zero/1.0/) applies to the data made available in this article, unless otherwise stated. 


\section{Background}

Chickens are important farm animals throughout the world, producing eggs and high quality meat for humans. Skeletal muscle mass and intramuscular fat content are both important traits for meat-producing chickens but attaining an appropriate muscle and fat ratio, reflecting the balance between muscle and adipose cells, is a great challenge for the broiler industry [1]. Muscle satellite cells (MSC) are skeletal muscle-specific stem cells, located between the basement membrane and sarcolemma of muscle fibers [2-4]. Through their proliferation and subsequent fusion with existing myofibers, MSC provide new myonuclei to the muscle fibers, making them crucial to postnatal growth and regeneration of skeletal muscle [5-7]. Intramuscular preadipocytes (IMPA) differentiate into mature adipocytes within bundles of muscle fibers, thereby contributing to flavor and shear characteristics, thus improving meat quality [8-10].

Intercellular communication is a fundamental process in biology, and an interaction exists between MSC and IMPA. Bovine preadipocytes increase expression of adipogenic genes in bovine satellite cells [11]. Satellite cell-derived myofibers of mice exerted a strongly inhibitory effect on adipogenesis of mesenchymal progenitors [12]. Similar results were obtained in porcine satellite cells that inhibited the differentiation of preadipocytes [13]. Both MSC and IMPA are derived from a common pool of mesenchymal stem cells and are located adjacent to each other; it is reasonable to suppose that there is intercellular communication between the two. There has been no study of the interactions between IMPA and MSC in chickens.

Co-culture of different cell types, separated by a permeable membrane, permits investigating interactions between distinct cell types, as it can mimic the in vivo cellular environment [14]. Medium constituents, including signaling molecules, exchange freely, thus effectuating cell-cell communication while preventing physical contact and admixing of the different cell populations enabling harvesting of the cells for subsequent analyses.

The present study has used a co-culture system to investigate the influence of IMPA on MSC in young chickens; transcriptome analysis was used to explore the underlying molecular mechanisms.

\section{Methods}

\section{Isolation of chicken muscle satellite cells and} intramuscular preadipocytes

The 7-day-old Beijing-You chickens were obtained from the experimental farm of the IAS (CAAS, Beijing, China). Primary cells were isolated as described previously with a slightly modification [15]. Chickens were stunned by electrical stunning $(120 \mathrm{~mA}, 50 \mathrm{~Hz})$ and then slaughtered with a quick, single cut to the throat. After sprayed with $75 \%$ ethanol, the pectoralis major muscle was isolated. The muscle was minced to $1 \mathrm{~mm}^{3}$ segments and digested for 60 min with $0.1 \% w / v$ type I collagenase (Gibco, Grand Island, NY). After terminating digestion with complete medium consisting of Dulbecco's modified Eagle's medium (DMEM)/F12 (Gibco), 10\% fetal bovine serum (FBS, Gibco), and 1\% penicillin/streptomycin (Gibco), the cell suspension was centrifuged at $350 \mathrm{~g}$ for $10 \mathrm{~min}$. The top layer containing mature adipocytes and the bottom pellet containing MSC were separately collected. The mature adipocyte layer was inoculated into a $25-\mathrm{cm}^{2}$ cell culture flask containing complete medium. The flask was incubated inverted for $6 \mathrm{~d}$ enabling adipocytes to attach to the upper surface and dedifferentiate, and subsequently re-inverted for another $6 \mathrm{~d}$ to allow the adherent cells to proliferate.

The cell pellet, containing MSC, was resuspended in complete medium, as above, filtered through 100- and $40-\mu \mathrm{m}$ sterile sieves, and then cultured in complete medium in 100-mm dishes. After cells were incubated for $2 \mathrm{~h}$, the medium containing unattached cells was transferred to a new dish, and purified MSC were obtained.

All cells were incubated in a humidified atmosphere of $5 \% \mathrm{CO} 2$ at $37{ }^{\circ} \mathrm{C}$. After reaching $80 \%$ confluence, both cell types were passaged with $0.25 \%$ trypsin-EDTA (Gibco), and passage 3 cells were used for further experiments.

\section{Co-culture of muscle satellite cells and intramuscular preadipocytes}

Cells were co-cultured using Transwell plates with 0.4- $\mu \mathrm{m}$ membrane inserts (Corning Inc., Kennebunk, $\mathrm{ME})$. The MSC $\left(2 \times 10^{5}\right.$ per well) were plated in the lower wells of the 6 -well plates, and IMPA $\left(1 \times 10^{5}\right.$ per well) were seeded into the upper inserts, initially in separate plates, i.e., not in a co-culture configuration. After both cell types reached confluence, the upper inserts containing IMPA were then transferred to the lower wells containing MSC to establish the co-cultures. The mono-cultured MSC served as controls. Following co-culture or mono-culture for 2 or $4 \mathrm{~d}$, MSC were harvested for further analysis. Comparisons between the two culture arrangements were made with 3 repetitions to allow for statistical evaluation.

\section{Immunofluorescence}

Myosin heavy chain (MHC) was used as a marker of MSC differentiation. After washing 3 times with PBS, the MSC were fixed in $4 \%$ paraformaldehyde for $20 \mathrm{~min}$, permeabilized in $0.25 \%$ Triton X-100 for $15 \mathrm{~min}$, and then blocked with $10 \%$ goat serum (CWBio, Beijing, China) for $30 \mathrm{~min}$. Subsequently, the cells were incubated with primary anti-MHC hybridoma supernatant (1:100, Developmental Studies Hybridoma Bank, Iowa City, IA) overnight at $4{ }^{\circ} \mathrm{C}$. After thorough washing, the cells were incubated in the dark for $1 \mathrm{~h}$ with fluorescein isothiocyanate (FITC)-conjugated goat anti-mouse IgG 
(1:100, CWBio, Beijing, China). Fluorescence signals of MSC in the lower chambers were detected and photographed by confocal fluorescence microscopy (Nikon TE-2000-E, Tokyo, Japan) [16].

\section{Oil red $O$ staining}

After $4 \mathrm{~d}$ of co-culture or mono-culture, the MSC were washed 3 times with PBS, fixed in $4 \%$ paraformaldehyde for $15 \mathrm{~min}$, and then stained with a $0.5 \%$ solution of Oil Red O in $60 \%$ isopropanol for $1 \mathrm{~h}$ at room temperature. The cells were washed 3 times with PBS, and the stained fat droplets in the MSC were visualized by light microscopy and photographed [17]. Isopropanol (100\%) was incubated for $10 \mathrm{~min}$ to extract Oil Red O from the cells and then the extracts were transferred to a 96-well-plate. The $\mathrm{OD}_{510}$ was measured photometrically with a microplate reader (Molecular Devices, SpectraMax M2, San Jose, CA) [18].

\section{RNA isolation and sequencing}

After co-culture or mono-culture for $2 \mathrm{~d}$, MSC were lysed by TRIzol reagent (Invitrogen Corp., Carlsbad, CA) and total RNA was extracted according to the manufacturer' protocol. The RNA concentration and integrity were assessed using a 2100 Bioanalyzer and RNA 6000 Nano Kit (Agilent Technologies, Santa Clara, CA) separately. RNA samples with an A260/A280 ratio between 1.8 and 2.0 and a RNA Integrity Number $>8.0$ were used for RNA sequencing and quantitative real-time PCR (qPCR). Based on ultra-high throughput sequencing (HiSeq 2500; Illumina, San Diego, CA), RNA-sequencing was performed by Annoroad Genomics (Beijing, China).

\section{Bioinformatics analysis of RNA-seq}

Sequence adapters and low quality reads (read quality $<30$ ) were removed using Trimmomatic (v0.32) [19]. Quality control checks on raw sequence data were performed with FastQC. Then, sequencing reads were mapped to the chicken reference genome [Ensembl Galgal4 (GCA_00 0002315.2)] using the HISAT(v2.0.4) program. To calculate the expression quantity of each transcript, alignment results were analyzed by the Cufflinks (v2.0.2) program. The FPKM (fragments per kilobase of transcript per million mapped fragments) method was used to quantify gene expression. Analyses of differential expression of transcripts were performed with edgeR (v2.2.5). Genes with a FDR value of less than $1 \%$ and fold-change $\geq 2$ were considered to be differentially expressed genes (DEG).

Principal component analysis (PCA) was performed to identify the variability and repeatability of samples. A volcano plot was used to visualize the overall distribution of differentially expressed genes. Gene ontology (GO) analysis of DEG was performed using DAVID functional annotation clustering [20]. Kyoto Encyclopedia of Genes and Genomes (KEGG) pathway enrichment analysis was performed by
KOBAS 3.0 (http://kobas.cbi.pku.edu.cn). Cytoscape was used to depict a pathway network of enriched pathways.

The significance level for GO terms and the KEGG pathway was set with the $P$-value $<0.05$.

\section{Quantitative real-time PCR}

The specific primers (Additional file 1: Table S1) were designed using Primer Premier 6.0 software, and were subsequently synthesized by the Sangon Biotech Corp (Shanghai, China). After reverse transcription, qPCR was performed using a SYBR Fast qPCR Master Mix (KAPA, Wilmington, MA).

The qPCR mixture contained $10 \mu \mathrm{L}$ of $2 \times \mathrm{iQ}^{\mathrm{m}}$ SYBR Green Supermix, $0.5 \mu \mathrm{L}(10 \mathrm{mM})$ of each primer and $20 \mathrm{ng}$ of cDNA, with $\mathrm{ddH}_{2} \mathrm{O}$ added to $20 \mu \mathrm{L}$. Samples were amplified using the real-time PCR Detection System ABI 7500 (Applied Biosystems, Shanghai, China). The PCR cycle parameters were as follows: $95{ }^{\circ} \mathrm{C}$ for $3 \mathrm{~min}$, then 40 cycles of $95{ }^{\circ} \mathrm{C}$ for $3 \mathrm{~s}$, and $60^{\circ} \mathrm{C}$ for $34 \mathrm{~s}$. The amplification procedure was performed with 3 repetitions for each sample. The $2^{-\Delta \Delta C t}$ method was used to calculate the relative abundance of transcripts [21].

\section{Statistical analysis}

All data are presented as the mean \pm standard deviation (SD), for 3 replicates from each experiment. Statistically significant differences between the 2 culture conditions were tested by independent-samples $t$-tests using SAS 9.2 software. $P<0.05$ (*) or $P<0.01$ (**) $^{*}$ was considered to be significant. All figures were constructed using GraphPad Prism version 5.02 (GraphPad Software Inc., La Jolla, CA).

\section{Results}

Differential expression analysis of mono-cultured and cocultured MSC

A total of 1653 known DEG, of which 922 were upregulated and 731 were downregulated, were identified in MSC that were co-cultured in the presence of IMPA $(|\log 2 \mathrm{FC}| \geq 1$ and FDR $<0.01$ ) (Fig. 1a and Additional file 2: Table S2).

To evaluate the consistency and variance of the 6 samples, PCA (based on all gene transcripts) and hierarchical clustering (based on all DEG) were performed. PCA demonstrated that the co-cultured and mono-cultured MSC were distinctly clustered (Fig $1 \mathrm{~b}$ ), and this was supported by the hierarchical clustering result (Fig. 1c), verifying acceptable repeatability in each and obvious difference between the culture conditions.

Accuracy of the RNA-seq data was examined by qPCR of 20 randomly chosen DEG and correlation between the 2 methods. Fold changes of the DEG were significantly correlated over a wide range $(r=0.96, P<0.01)$ (Fig. 1d), confirming reliability of the RNA-seq results. 


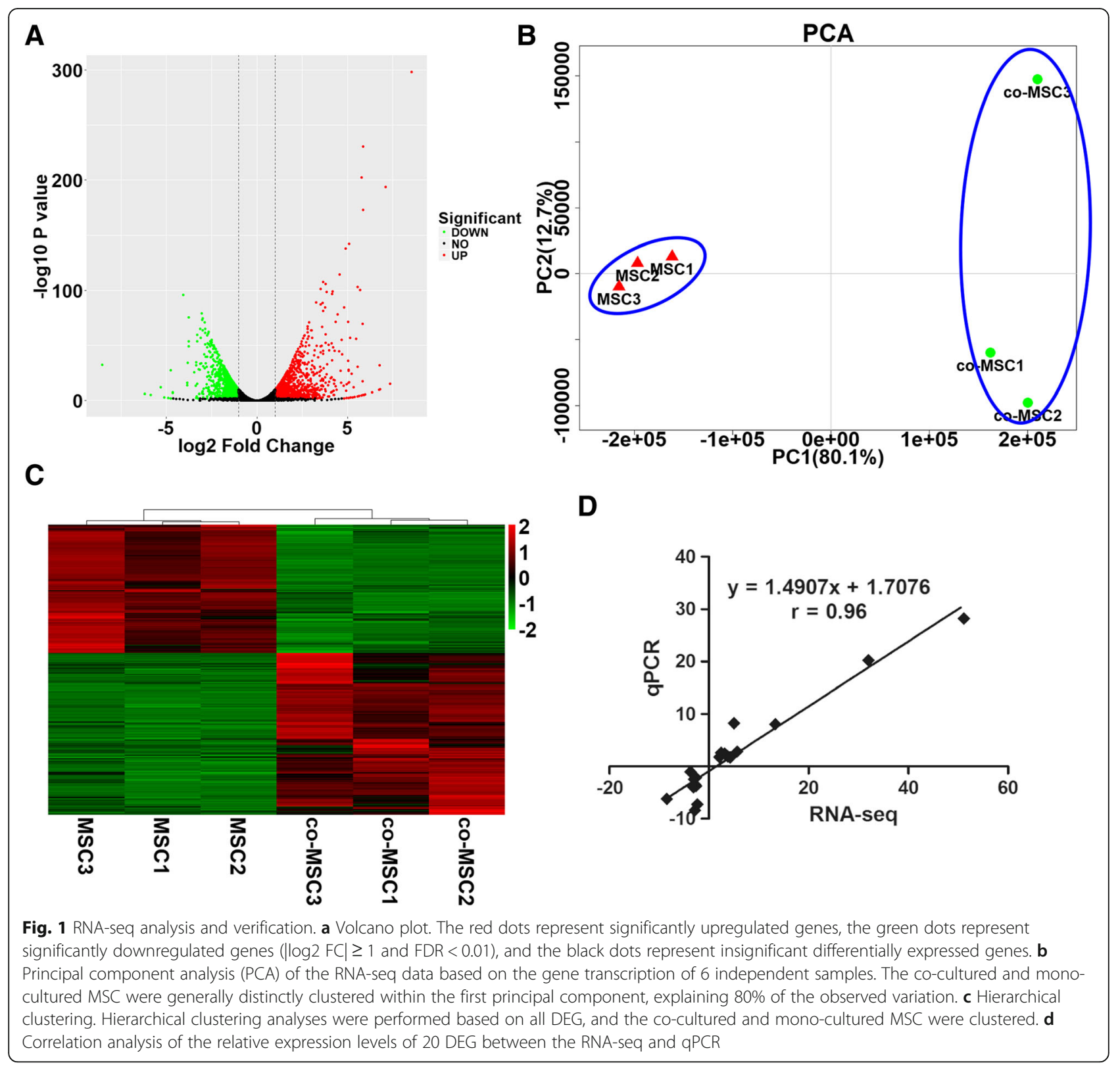

\section{Functional enrichment analysis of the DEG}

The function of the known DEG was examined by GO enrichment analysis. A total of 75 Biological Process (BP) terms were significantly enriched $(P<0.05)$ (Additional file 3: Table S3). These BP terms were mainly associated with muscle development, lipid metabolism, ossification, angiogenesis, cell activities (cell growth, adhesion, migration, and differentiation), regulation of ion transmembrane transport, protein phosphorylation, and signal transduction $(P<0.05)$. The DEG related to muscle development and lipid deposition were examined further. There were 48 DEG related to muscle differentiation and development, including the key genes MYOD1, MYOG, PAX7, and TMEM8C (Additional file 4:
Table S4). The 44 DEG related to lipid deposition included the key genes CD36, FABP4, ACSBG2, CYP7A1 and PLIN2 (Additional file 5: Table S5).

After KEGG pathway analysis, 20 pathways were significantly enriched (Fig. 2 and Additional file 6: Table S6). Consistent with the GO results, several of these pathways were related to muscle development and contraction, including MAPK signaling, Adrenergic signaling in cardiomyocytes, Cardiac muscle contraction, Vascular smooth muscle contraction, and Calcium signaling pathway. Many of the pathways were involved in lipid deposition, including PPAR signaling, Glycosphingolipid biosynthesis, and $\mathrm{ABC}$ transporters. In addition, six enriched pathways were related to cell junction, 


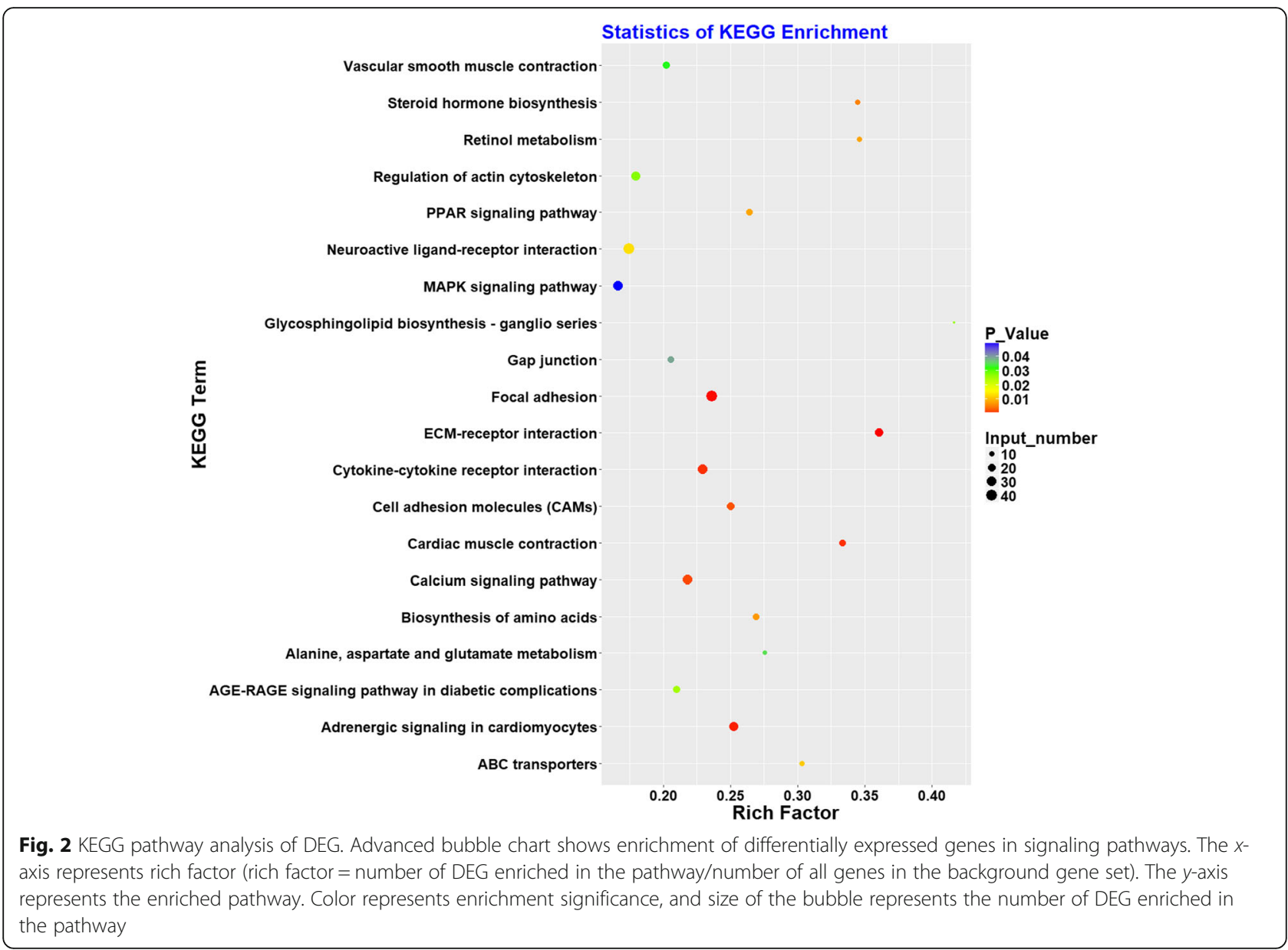

including extracellular matrix (ECM)-receptor interaction, Focal adhesion, Cell adhesion molecules (CAMs), Gap junction, Cytokine-cytokine receptor interaction, and Regulation of actin cytoskeleton.

\section{IMPA constrain differentiation of MSC}

Of the 48 DEG related to muscle development, 15 DEG were related to skeletal muscle cell differentiation, 12 DEG were related to myofibril and myosin, 14 DEG were related to muscle organ development and 7 DEG were related to muscle contraction (Table 1). The majority (83.3\%) of DEG related to muscle development were significantly downregulated in MSC that were co-cultured, indicating that differentiation of MSC was reduced by the influence of IMPA.

To explore this negative influence of IMPA on MSC differentiation, transcript abundance of 5 key genes involved in muscle differentiation was quantified by qPCR. In addition, immunofluorescence was used to explore MHC (the major marker of terminal myogenic differentiation, encoded by MYH1E) to directly assess differentiation of MSC. Compared with mono-cultured MSC, the abundance of MYOD1, MYH1E, PAX7, TMEM8C, and
MYOG transcripts was significantly downregulated in co-cultured MSC on day 2 (Fig. 3a). Immunofluorescence results showed that MHC-positive cells were also reduced in number in co-cultured MSC on day 2 (Fig. $3 \mathrm{~b})$. These results confirmed that IMPA suppressed differentiation of the MSC.

\section{IMPA promote lipid accumulation in MSC}

Of the 44 DEG related to lipid deposition, 19 DEG related to fatty acid binding and transport, 13 related to fat cell differentiation, and 12 related to cholesterol metabolism (Table 2). The majority (81.8\%) of DEG related to lipid deposition were significantly upregulated in co-cultured MSC, indicating that IMPA promoted lipid deposition in the MSC.

This influence of IMPA on lipid deposition in MSC was examined by qPCR of transcripts of 5 key genes involved in lipid deposition in MSC that were co-cultured for 2 days. The transcript abundance of FABP4, CD36, $A P O A 1, D I S P 3$, and $A D I P O Q$ was all significantly upregulated in co-cultured MSC on day 2 (Fig. 4a). Staining with Oil Red $\mathrm{O}$ on day 4 demonstrated that there were more lipid droplets in co-cultured MSC, which further 
Table 1 DEG related to muscle differentiation and development

\begin{tabular}{|c|c|c|c|c|c|}
\hline Terms & Gene name & Fold change & Terms & Gene name & Fold change \\
\hline \multirow[t]{15}{*}{ muscle organ development (13/14) } & $S G C D$ & 0.46 & skeletal muscle cell differentiation (10/15) & MYOG & 0.33 \\
\hline & $C R Y A B$ & 0.32 & & MYOD1 & 0.39 \\
\hline & JPH1 & 0.19 & & ANKRD1 & 0.19 \\
\hline & SGCG & 0.35 & & ASB2 & 0.24 \\
\hline & $A L X 4$ & 0.48 & & SMYD1 & 0.29 \\
\hline & TNNT2 & 0.50 & & ACTA1 & 0.44 \\
\hline & TNNC1 & 0.42 & & FAM65B & 0.37 \\
\hline & TPM1 & 0.40 & & HOMER1 & 0.39 \\
\hline & ACTA2 & 0.38 & & TMEMBC & 0.28 \\
\hline & ACTC1 & 0.42 & & NTN3 & 0.26 \\
\hline & TAGLN & 0.44 & & HEYL & 3.82 \\
\hline & PVALB & 0.39 & & BTG2 & 2.94 \\
\hline & CASQ2 & 0.37 & & GPX1 & 2.75 \\
\hline & $M B$ & 2.73 & & CXCL14 & 4.23 \\
\hline & & & & HOPX & 2.82 \\
\hline \multirow[t]{12}{*}{ myofibril and myosin (11/12) } & MYL1 & 0.30 & & & \\
\hline & CALD1 & 0.46 & muscle contraction $(6 / 7)$ & SYNM & 0.43 \\
\hline & MYL4 & 0.45 & & LMOD2 & 0.29 \\
\hline & MYH13 & 0.13 & & STAC & 0.16 \\
\hline & MYH10 & 0.44 & & ACTN2 & 0.39 \\
\hline & MYO5A & 0.48 & & MYOM2 & 0.31 \\
\hline & MYO1H & 0.48 & & LMOD1 & 0.41 \\
\hline & MYO16 & 0.13 & & CLCN1 & 2.90 \\
\hline & MYH1E & 0.28 & & & \\
\hline & MYH15 & 0.28 & & & \\
\hline & CFL2 & 0.50 & & & \\
\hline & MYO1F & 2.84 & & & \\
\hline
\end{tabular}

The first number in the parentheses represents the downregulated genes, and the second represents the total genes involved in the term

confirmed that IMPA promoted lipid deposition in MSC (Fig. 4b).

\section{Pathways related to differentiation and lipid deposition in MSC}

As differentiation of muscle cells and their lipid deposition are complex processes, the underlying molecular mechanisms may involve interactions between multiple signaling pathways.

The pathway network of interconnected signals was constructed on the basis of the KEGG pathway database. As shown in Fig. 5a, the calcium signaling pathway and MAPK signaling pathway were the two most interactive pathways. Calcium signaling tightly interacted with pathways related to muscle contraction, and MAPK signaling interplayed with cell junction related pathways. The MAPK signaling pathway functioned downstream of calcium signaling. Thus, MAPK signaling may be the key pathway involved in the present study.

The MAPK signaling pathway contains 4 distinct cascades, ERK1/2, JNK/MAPK, p38-MAPK and ERK5, all of which have been demonstrated to be involved in skeletal myogenesis [22]. The data obtained here indicate that DEG were seldom enriched in the p38-MAPK and ERK5 pathways, and just a few DEG were enriched in the ERK1/2 pathway (Fig. 5b). In contrast, many DEG were enriched in JNK/MAPK signaling, including $R a c 2, M A P 3 K 8, A R R 3$, the core effector JNK (MAPK10), and its downstream effector c-JUN $(J U N)$, all indicating that the JNK/MAPK signaling pathway may be the key pathway influencing differentiation of MSC.

Apart from muscle differentiation, MAPK signaling is also involved in lipid metabolism [23, 24]. PPAR signaling occurred downstream of MAPK signaling, and 


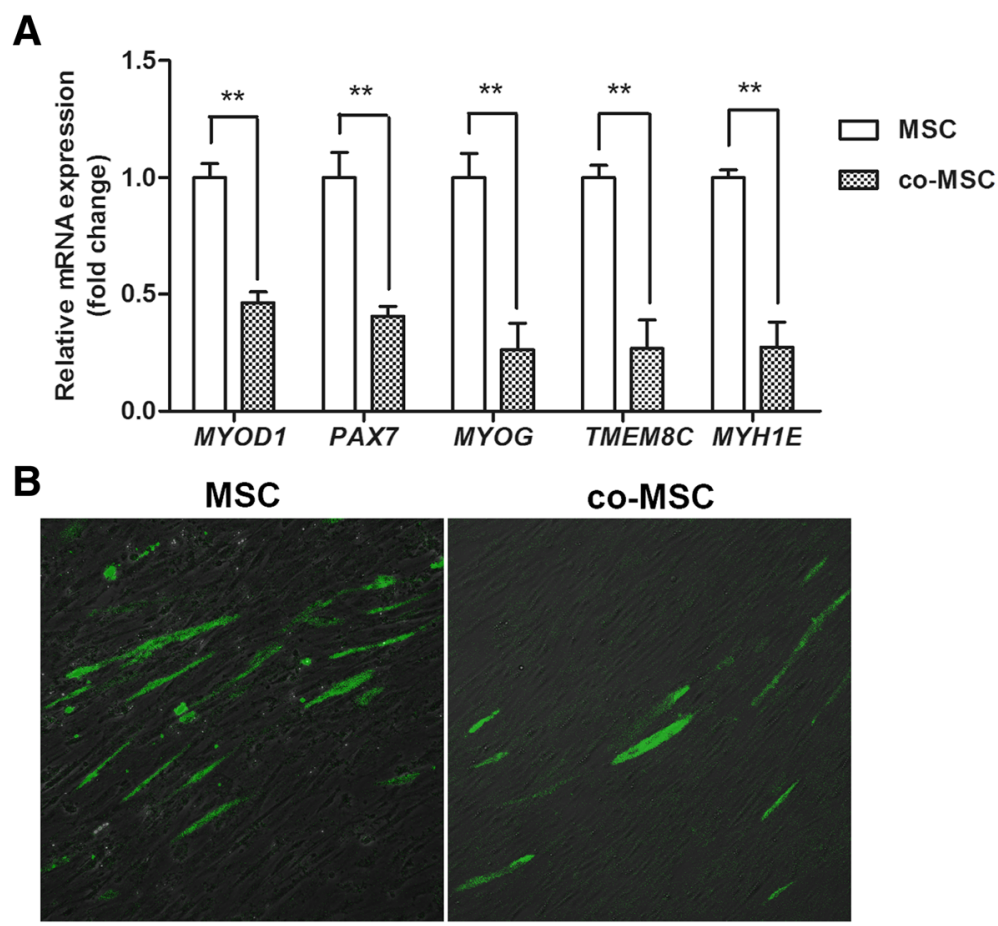

Fig. 3 Myogenic differentiation of MSC is reduced by co-culture with IMPA. a qPCR assays of transcripts of 5 key genes (MYOD1, PAX7, MYOG, TMEMBC and MYHIE) related to myogenic differentiation in co-cultured or mono-cultured MSC on day 2 . The key genes related to myogenic differentiation were all downregulated in co-cultured MSC. The data are expressed as the mean \pm SD $(* * P<0.01)$. $\mathbf{b}$ Immunofluorescent staining of myosin heavy chain (MHC) in co-cultured or mono-cultured MSC on day 2 indicating fewer MHC-positive cells in co-cultured MSC

numerous critical genes including CD36, FABP4, $A D I$ POQ, APOA1, CYP7A1, PLIN2, and SLC27A1 were enriched in this pathway, consistent with PPAR signaling being the key pathway regulating lipid deposition in MSC.

Pathways related to cell junctions (ECM-receptor interaction, focal adhesion, regulation of actin cytoskeleton, and gap junction) might form a regulatory network with the MAPK signaling pathway and contribute to the differentiation of MSC and their lipid deposition.

\section{Discussion}

Chickens are very important food animals worldwide and, because all embryonic stages are readily available, they have been widely used as a model for muscle development studies [25]. The skeletal muscle mass is a crucial trait for the economic yield of chickens, and in turn, is largely dependent on the proliferation and differentiation of MSC [3]. This study is the first to investigate the effects of IMPA on MSC in chickens and unveil the molecular mechanisms by transcriptome analysis. The experimental model used MSC, cultured alone or co-cultured so that the influence of IMPA on the MSC could be determined.
The repeatability within and differences between samples of mono-cultured or co-cultured MSC were examined by PCA and hierarchical clustering. There was good repeatability among the replicate samples of each culture treatment and distinction between mono-culture and co-culture. The RNA-seq results for 20 transcripts were well-supported by the qPCR data.

Based on GO terms, 48 and 44 of the 1653 known DEG found here were related to muscle development and lipid deposition. Most of the DEG related to muscle development were downregulated in co-cul tured MSC, and DEG related to lipid deposition were upregulated. Immunofluorescence of MHC supported IMPA inhibiting differentiation of MSC, and Oil Red $\mathrm{O}$ staining showed concurrent promotion of lipid deposition. This duality of action has not been previously described.

Muscle cell differentiation includes cell migration, cell alignment, and cell fusion and can be expected to result from complex pathway interactions [26, 27]. Muscle cell differentiation occurs under the control of several factors such as myogenic regulatory factors (MRFs) and Pax7 [28-30]. MRFs, including MyoD, Myf5, MyoG, and MRF6, have critical roles in skeletal muscle cell commitment and differentiation [31, 32]. 
Table 2 DEG related to lipid deposition

\begin{tabular}{|c|c|c|c|c|c|}
\hline Terms & Gene name & Fold change & Terms & Gene name & Fold change \\
\hline \multirow[t]{20}{*}{ fatty acid binding and transport (16/19) } & $A P O D$ & 6.30 & fat cell differentiation (10/13) & HTR2C & 2.56 \\
\hline & FABP4 & 13.75 & & LAMA4 & 11.81 \\
\hline & FABP5 & 3.95 & & $M B$ & 2.73 \\
\hline & LCN8 & 372.31 & & RGS2 & 12.18 \\
\hline & PLIN2 & 4.55 & & SFRP2 & 2.14 \\
\hline & PMP2 & 9.79 & & SNAI2 & 2.51 \\
\hline & PTGDS & 137.17 & & TPH1 & 9.32 \\
\hline & RBP $4 A$ & 5.16 & & ITGA6 & 0.36 \\
\hline & RBP5 & 2.52 & & PTGS2 & 0.43 \\
\hline & RBP7 & 5.37 & & $Z B T B 7 C$ & 0.40 \\
\hline & SLC27A1 & 3.32 & & & \\
\hline & FADS6 & 5.95 & cholesterol metabolism (10/12) & $A B C A 1$ & 6.99 \\
\hline & CD36 & 3.46 & & $A B C G 1$ & 13.89 \\
\hline & ANGPTL4 & 11.38 & & $A P O A 1$ & 58.55 \\
\hline & ACSBG2 & 2.14 & & APOA4 & 5.49 \\
\hline & ACSL5 & 2.89 & & $\mathrm{CH} 25 \mathrm{H}$ & 2.22 \\
\hline & SLC45A3 & 0.33 & & DISP3 & 2.28 \\
\hline & ACSL6 & 0.27 & & $\angle E P R$ & 5.05 \\
\hline & $S C D$ & 0.45 & & SOAT1 & 2.03 \\
\hline & & & & CYP17A1 & 5.33 \\
\hline \multirow[t]{3}{*}{ fat cell differentiation (10/13) } & ADIPOQ & 4.13 & & CYPTA1 & 12.82 \\
\hline & $C C D C 3$ & 5.71 & & INSIG1 & 0.49 \\
\hline & HTR2A & 2.38 & & NSDHL & 0.46 \\
\hline
\end{tabular}

The first number in the parentheses represents the upregulated genes, and the second represents the total genes involved in the term

MyoD functions in commitment to satellite cell activation, proliferation, and differentiation [33]. MyoG has a crucial role in the terminal differentiation of muscle cells [32]. Pax7 belongs to the paired box transcription factor family, which can regulate the developmental processes of embryonic myoblasts [34], and Pax7 activates myogenic regulatory factors MyoD and Myf5. In addition, myomaker (TMEM8C), a newly discovered muscle-specific transmembrane protein, is directly involved in cell fusion and it stimulates myoblast fusion in chickens and mammals [3538]. In the present study, transcripts of MYOD1, MYOG, PAX7, and TMEM $8 C$ were all significantly reduced in co-cultured MSC, which is consistent with the reduced numbers of MHC-positive cells. These genes, therefore, may be the key genes mediating the effect of IMPA on differentiation of the MSC.

It appeared that MAPK signaling was central to the pathway network whereby IMPA influenced the MSC. Many key DEG were enriched in JNK/MAPK signaling. The present findings are consistent with a recent study suggesting that JNK/MAPK signaling inhibits skeletal muscle differentiation by negatively regulating
MyoD [39]. The proposed molecular regulatory mechanism by which co-culture with IMPA affected MSC is given in Fig. 6. Signaling via JNK/MAPK is mediated initially by IMPA triggering the upstream kinase Rac2 and subsequently activating MAP3K8, leading to activation of MAPK10. The activated MAPK10 next activates its downstream effector JUN, and transcriptional factors MyoD and MyoG were further downregulated. Finally, the downregulated MyoD and MyoG inhibited differentiation of MSC.

The formation of lipid droplets is a highly conserved process that involves the activation of fatty acids, synthesis of neutral lipid, and the formation of droplets, involving the products of many genes and pathway interactions [40]. CD36 and SLC27A1 are both fatty acid transport proteins involved in the translocation of long-chain fatty acids [41, 42]. FABP4, fatty acid binding protein 4, plays a role in intracellular lipid transport [43]. ACSBG2 and ACSL5 are both acyl-CoA synthetases, playing a critical role in the activation of fatty acids via esterification with coenzyme-A [44]. In addition, DISP3 and CYP7A1 play a role in the accumulation of cellular cholesterol 
A
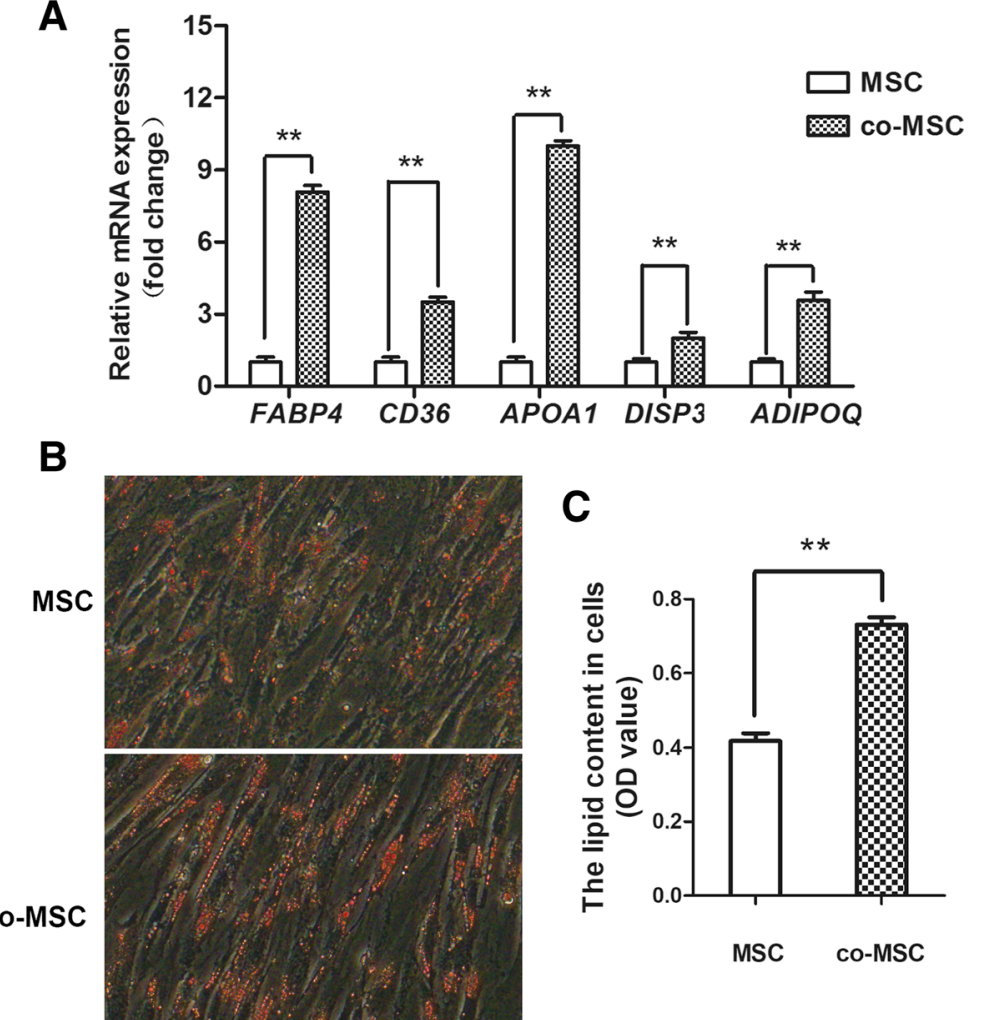

Fig. 4 Lipid deposition increased in MSC co-cultured with IMPA. a qPCR assays of transcripts of 5 key genes (FABP4, CD36, APOA 1, DISP3, and $A D I P O Q)$ related to lipid deposition of co-cultured or mono-cultured MSC on day 2. These genes were all upregulated in co-cultured MSC. The data are expressed as the mean \pm SD $\left({ }^{* *} P<0.01\right)$. b Oil Red O staining showed that co-cultured MSC contained more lipid droplets on day 4 . $\mathbf{c}$ $\mathrm{OD}_{510}$ values of Oil Red $\mathrm{O}$ uptake by co-cultured and mono-cultured MSC on day 4 . The data are expressed as the mean $\pm S D(* * P<0.01$ )

and are involved in droplet formation [45]. PLIN2, located on the droplet surface, is the predominant perilipin in skeletal muscle and is upregulated during droplet formation, forming a protective coat inhibiting lipolysis [46-48]. In the present study, CD36, SLC27A1, FABP4, ACSBG2, ACSL5, DISP3, CYP7A1, and PLIN2 were all upregulated in co-cultured MSC, consistent with their increased numbers of lipid droplets. Thus, these 8 genes might be key genes involved in the effect of IMPA on lipid deposition in MSC (Fig. 6).

Of these 8 genes, 7 were involved in PPAR signaling, indicating that it might be the key pathway for lipid deposition in MSC, as reflected in the observations from Oil Red $\mathrm{O}$ staining. In addition to the proposed role of MAPK signaling in muscle differentiation, it is also involved in lipid metabolism $[49,50]$. Several studies have shown that MAPK signaling could modulate PPAR [51, 52], consistent with the present conclusion that this mediated the effect of IMPA in promoting lipid deposition in MSC.

Several pathways related to cell junctions were also enriched in co-cultured MSC, including ECM-receptor interaction, Focal adhesion, CAMs, Gap junction, Cytokine-cytokine receptor interaction and Regulation of actin cytoskeleton, all of which were closely interrelated. Focal adhesion is a cluster of integrin transmembrane receptors that mediate dynamic interactions between the extracellular matrix and the actin cytoskeleton $[53,54]$. In the present study, a series of genes encoding integrins (ITGA4, ITGA6, ITGA8, ITGA9, ITGAV and $I T G B 8)$ were differentially expressed. These genes simultaneously participated in 4 pathways (ECM-receptor interaction, focal adhesion, CAMs, and regulation of actin cytoskeleton). In addition, PDGFRA and PDGFRB encoded proteins correlated with Focal adhesion, Gap junction, Cytokine-cytokine receptor interaction, and Regulation of actin cytoskeleton.

These cell junction-related pathways broadly participate in muscle differentiation [55-57]. During the process of differentiation of MSC, significant changes take place in cell morphology, ECM components, and actin cytoskeleton remodeling. [58]. In addition, several studies suggest that cell junction-related pathways are also involved in lipid deposition [52, 59, 60]. 


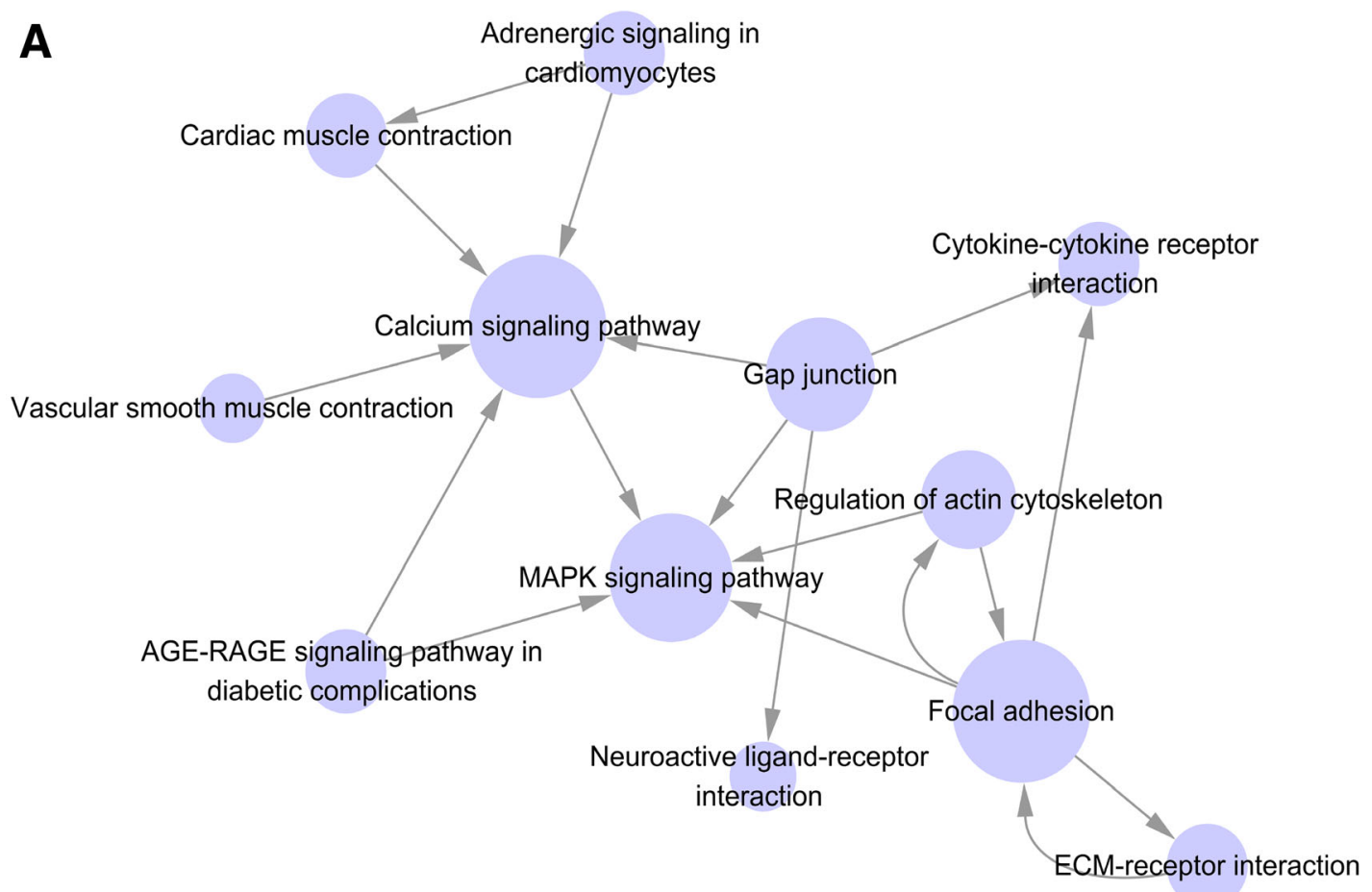

B

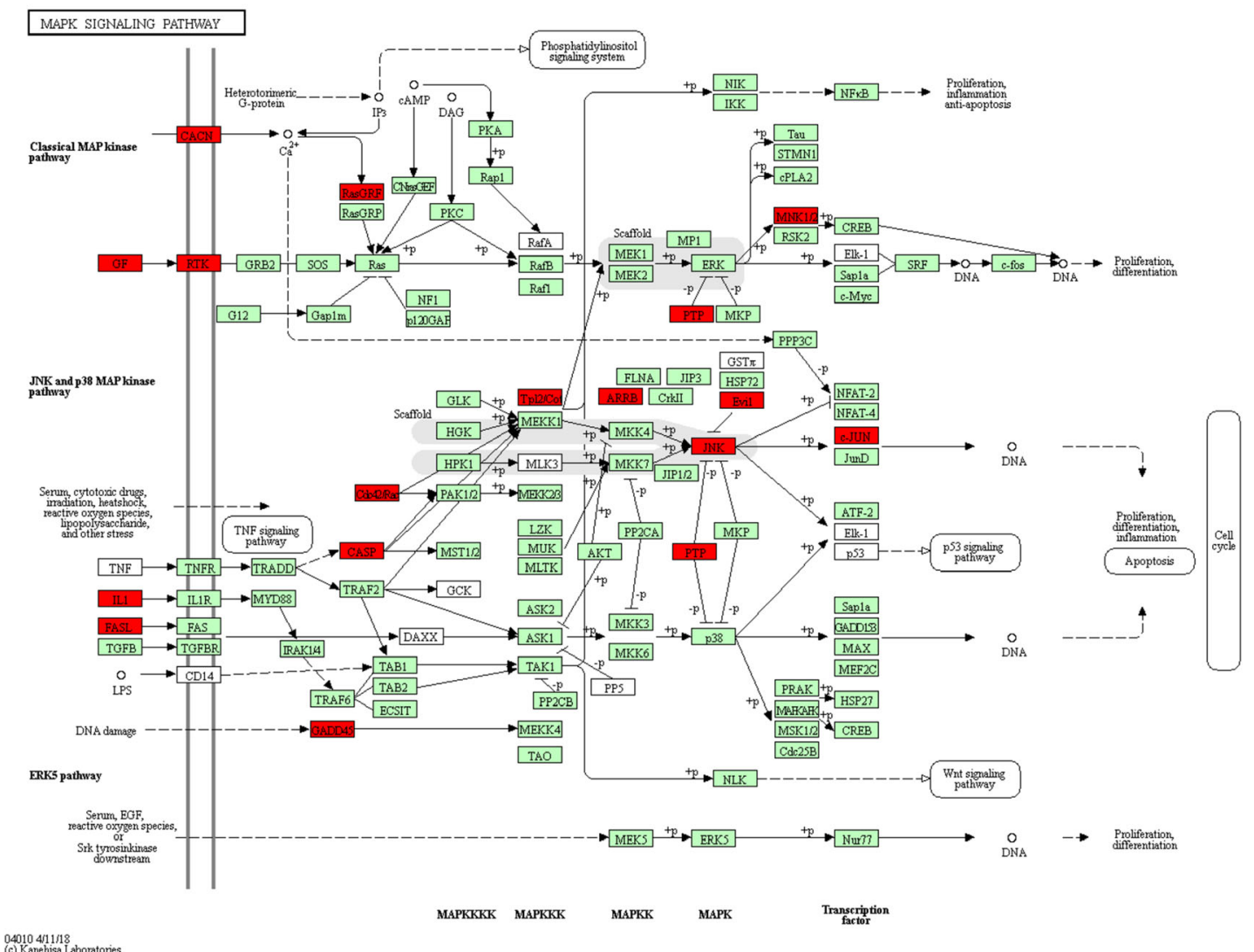

Fig. 5 (See legend on next page.) 
(See figure on previous page.)

Fig. 5 Pathway network and MAPK signaling. a The pathway network of interconnected signals was constructed based on the KEGG pathway database and literature. The calcium signaling pathway and MAPK signaling pathway were the two most interactive pathways. The calcium signaling pathway tightly interacted with pathways related to muscle contraction, and MAPK signaling interplayed with cell junction-related pathways. $\mathbf{b}$ The MAPK signaling pathway was enriched in the present study. The DEG are highlighted in red. The MAPK signaling pathway contains 4 distinct cascades, ERK1/2, JNK/MAPK, P38-MAPK, and ERK5. Few DEG were enriched in ERK1/2 signaling, but several DEG were enriched in JNK signaling

Several of the DEG identified here in co-cultured versus mono-cultured MSC (FGF12, FGF16, FGF19 and FGF9) belonging to the FGF family were reflected in MAPK signaling and also participated in the regulation of the actin cytoskeleton. It seems likely that pathways related to cell junctions may form a regulatory network with MAPK signaling and contribute to differentiation and lipid deposition in MSC.

We have developed a novel co-culture system designed to mimic the physiologic interactions between skeletal muscle cell and intramuscular preadipocytes. Our results demonstrated that intramuscular preadipocytes inhibited muscle cell differentiation and promoted lipid deposition. A deep understanding of cross-talk between muscle cells and intramuscular adipocytes could be utilized to improve meat quality in chickens. In humans, excessive intracellular lipid accumulation in skeletal muscle is associated with some metabolic diseases such as insulin resistance and type 2 diabetes [61-63]. The data suggest that some factor secreted by adipocytes induced intracellular lipid accumulation in muscle cells, which provide important insights for livestock meat quality and human metabolic disease.

\section{Conclusions}

This study with chicken cells showed that IMPA impeded differentiation of MSC while promoting their lipid deposition. KEGG pathway analysis indicated that IMPA might inhibit differentiation via the JNK/MAPK

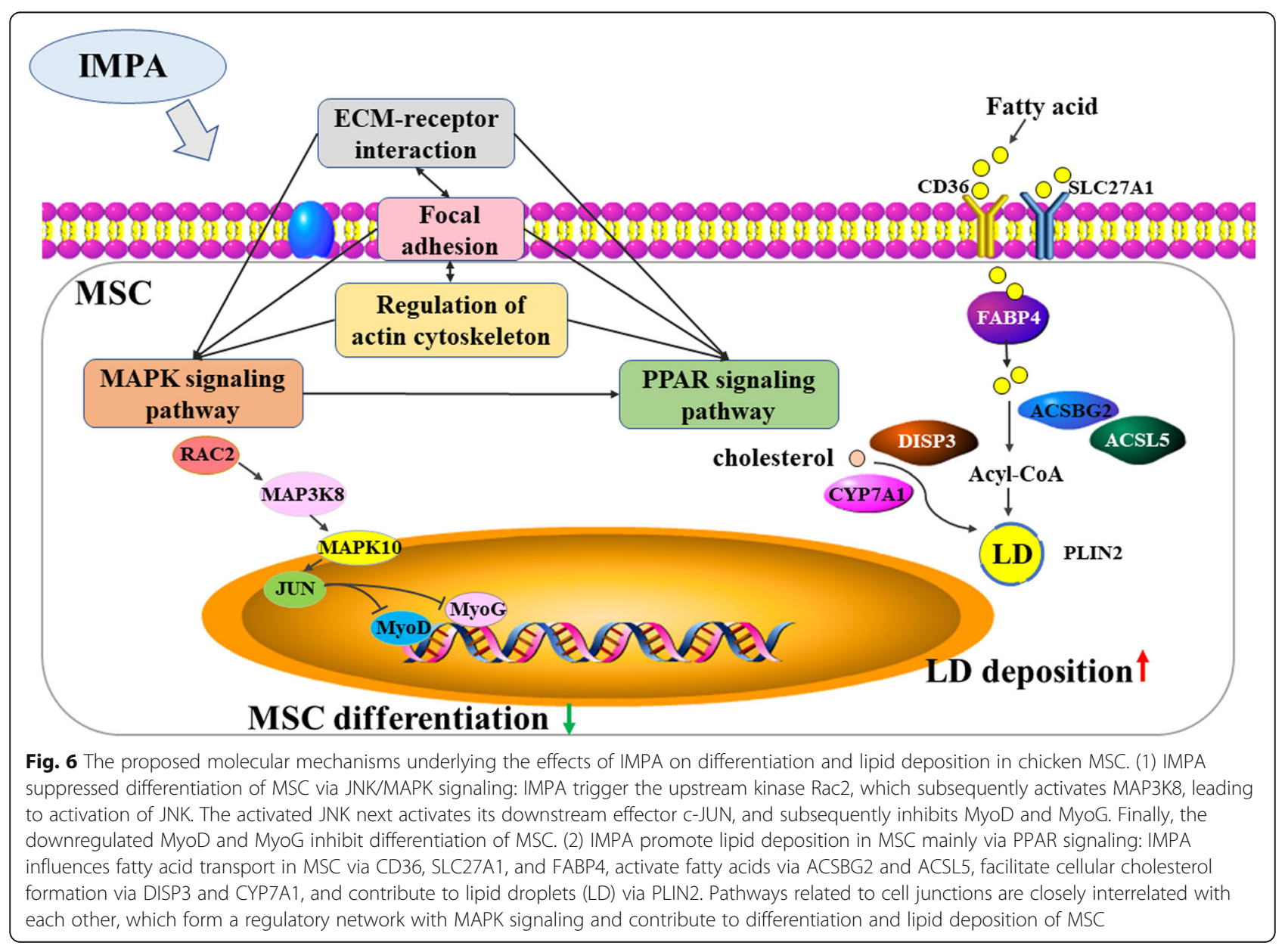


pathway, and promote lipid deposition via the PPAR pathway. Pathways related to cell junctions may also contribute to differentiation and lipid deposition in MSC. Although much experimentation is required to develop these predictions, they provide new clues for exposing the molecular mechanisms underlying the interplay between skeletal muscle and intramuscular fat in chickens.

\section{Additional files}

\author{
Additional file 1: Table $\mathbf{S 1}$. The specific primers for $\mathrm{QPCR}$ in this study. \\ (XLSX $12 \mathrm{~kb}$ ) \\ Additional file 2: Table S2. The screened DEG in the study. (XLSX \\ $218 \mathrm{~kb}$ )
}

Additional file 3: Table S3. The enriched GO-terms based on 1653 DEG. (XLSX 19 kb)

Additional file 4: Table S4. The DEG related to myogenic differentiation and muscle development. (XLSX 14 kb)

Additional file 5: Table S5. The DEG related to lipid deposition. (XLSX $14 \mathrm{~kb})$

Additional file 6: Table S6. The enriched pathways based on 1653 DEG. (XLSX $16 \mathrm{~kb}$ )

\section{Abbreviations}

ACSBG2: Long chain fatty acid CoA ligase; ADIPOQ: Adiponectin; APOA1: Apolipoprotein A1; ARR3: Arrestin 3; BP: Biological Process; CAMs: Cell adhesion molecules; CD36: CD36 molecule; CYP7A1: Cholesterol 7 alpha monooxygenase; DEG: Differentially expressed genes; DISP3: Dispatched RND transporter family member 3; DMEM: Dulbecco's modified Eagle's medium; ECM: Extracellular matrix; ERK1/2: The extracellular signal- related kinases; FABP4: Fatty acid binding protein 4; FGF12: Fibroblast growth factor 12; FGF16: Fibroblast growth factor 16; FGF19: Fibroblast growth factor 19; FGF9: Fibroblast growth factor 9; FNDC5: Fibronectin type III domain containing 5; GO: Gene Ontology; HOMER1: Homer scaffolding protein 1; IGF2: Insulin like growth factor 2; IMPA: Intramuscular preadipocytes; ITGA4: Integrin subunit alpha 4; ITGA6: Integrin subunit alpha 6; ITGA8: Integrin subunit alpha 8; ITGA9: Integrin subunit alpha 9; ITGAV: Integrin alpha-V; ITGB8: Integrin beta 8; JNK: C-Jun N-terminal kinases; JUN: Transcription factor AP-1; KEGG: Kyoto Encyclopedia of Genes and Genomes; LD: Lipid droplet; MAPK: Mitogen-activated protein kinase; MF: Molecular Function; MHC: Myosin heavy chain; MRFs: Myogenic regulatory factors; MSC: Muscle satellite cells; Myf5: Myogenic factor 5; MYF6: Myogenic factor 6; MYH10: Myosin Heavy Chain 10; MYH13: Myosin Heavy Chain 13; MYH15: Myosin Heavy Chain 15; MYH1E: Myosin Heavy Chain 1; MYL1: Myosin Light Chain 1; MYL4: Myosin Light Chain 4; MYO16: Myosin XVl; MyoD: Myogenic differentiation; MyoG: Myogenin; NTN3: Netrin1; PCA: Principal component analysis; PDGFRA: Platelet-derived growth factor receptor alpha; PDGFRB: Platelet-derived growth factor receptor beta; PLIN2: Perilipin 2; PPAR: Peroxisome proliferators-activated receptors; Rac2: Rac family small GTPase 2; SLC27A1: Long-chain fatty acid transport protein 1; TMEM8C: Transmembrane protein $8 \mathrm{C}$

\section{Acknowledgments}

The authors appreciate W. Bruce Currie (emeritus professor, Cornell University, Ithaca, NY) for contributions to the revising of the manuscript, and Dr. Jason Qee (Editor in Chief of the Editorbar Language Editing, Beijing, China) for providing the English edits on this manuscript.

\section{Funding}

The research was supported by grants from the National Natural Science Foundation of China (31372305), the Agricultural Science and Technology Innovation Program (ASTIP-IAS04, ASTIP-IAS-TS-18), the Earmarked Fund for Modern Agro-Industry Technology Research System (CARS-41), and Chinese Academy of Agricultural Sciences Institute of Animal Sciences Basic Research.

\section{Authors' contributions}

LPG performed of the study, analyzed the data, and drafted the manuscript. HXC contributed to the design of the study, analysis of data and modifying the manuscript. GPZ contributed to the design the study, the interpretation of data, and modifying the manuscript. RRL \& QHL \& MQZ contributed to interpretation of data and revising of the manuscript. JW \& YMG contributed to conception and design of the study and revising the manuscript. All authors submitted comments on drafts, and read and approved the final manuscript.

\section{Ethics approval}

All experimental procedures with chickens were performed according to the Guidelines for Experimental Animals established by the Ministry of Science and Technology (Beijing, China). Ethical approval on animal survival was given by the animal ethics committee of the Institute of Animal Sciences (IAS), Chinese Academy of Agricultural Sciences (CAAS, Beijing, China).

\section{Consent for publication}

Not applicable.

\section{Competing interests}

The authors declare that they have no competing interests.

\section{Publisher's Note}

Springer Nature remains neutral with regard to jurisdictional claims in published maps and institutional affiliations.

\section{Author details}

${ }^{1}$ Institute of Animal Sciences, Chinese Academy of Agricultural Sciences, Beijing 100193, China. ${ }^{2}$ College of Animal Science and Technology, China Agricultural University, Beijing 100193, China. ${ }^{3}$ State Key Laboratory of Animal Nutrition, Beijing 100193, China.

Received: 2 May 2018 Accepted: 30 October 2018

Published online: 26 November 2018

References

1. Li F, Li Y, Duan Y, Hu CA, Tang Y, Yin Y. Myokines and adipokines: involvement in the crosstalk between skeletal muscle and adipose tissue. Cytokine Growth Factor Rev. 2017;33:73-82.

2. Asakura A, Komaki M, Rudnicki MA. Muscle satellite cells are multipotential stem cells that exhibit myogenic, osteogenic, and adipogenic differentiation. Differentiation. 2001;68(4-5):245-53.

3. Sun WJ, He T, Qin CF, Qiu K, Zhang X, Luo YH, Li DF, Yin JD. A potential regulatory network underlying distinct fate commitment of myogenic and adipogenic cells in skeletal muscle. Sci Rep-Uk. 2017;7:14

4. De Coppi P, Milan G, Scarda A, Boldrin L, Centobene C, Piccoli M, Pozzobon M, Pilon C, Pagano C, Gamba P, et al. Rosiglitazone modifies the adipogenic potential of human muscle satellite cells. Diabetologia. 2006;49(8):1962-73.

5. Sacco A, Doyonnas R, Kraft P, Vitorovic S, Blau HM. Self-renewal and expansion of single transplanted muscle stem cells. Nature. 2008;456(7221):502-6.

6. Montarras D, Morgan J, Collins C, Relaix F, Zaffran S, Cumano A, Partridge T, Buckingham M. Direct isolation of satellite cells for skeletal muscle regeneration. Science. 2005;309(5743):2064-7.

7. Dumont NA, Bentzinger CF, Sincennes MC, Rudnicki MA. Satellite cells and skeletal muscle regeneration. Compr Physiol. 2015;5(3):1027-59.

8. Mortimer SI, van der Werf JH, Jacob RH, Hopkins DL, Pannier L, Pearce KL, Gardner GE, Warner RD, Geesink GH, Edwards JE, et al. Genetic parameters for meat quality traits of Australian lamb meat. Meat Sci. 2014;96(2 Pt B):1016-24.

9. Zhao XH, Yang ZQ, Bao LB, Wang CY, Zhou S, Gong JM, Fu CB, Xu LJ, Liu CJ, Qu M. Daidzein enhances intramuscular fat deposition and improves meat quality in finishing steers. Exp Biol Med (Maywood). 2015;240(9):1152-7.

10. Zomeno C, Blasco A, Hernandez P. Divergent selection for intramuscular fat content in rabbits. II. Correlated responses on carcass and meat quality traits. J Anim Sci. 2013:91(9):4532-9.

11. Choi SH, Chung KY, Johnson BJ, Go GW, Kim KH, Choi CW, Smith SB. Coculture of bovine muscle satellite cells with preadipocytes increases PPARgamma and C/EBPbeta gene expression in differentiated myoblasts and increases GPR43 gene expression in adipocytes. J Nutr Biochem. 2013; 24(3):539-43. 
12. Uezumi A, Fukada S, Yamamoto N, Takeda S, Tsuchida K. Mesenchymal progenitors distinct from satellite cells contribute to ectopic fat cell formation in skeletal muscle. Nat Cell Biol. 2010;12(2):143-52.

13. Li YH, Li FN, Lin BB, Kong XF, Tang YL, Yin YL. Myokine IL-15 regulates the crosstalk of co-cultured porcine skeletal muscle satellite cells and preadipocytes. Mol Biol Rep. 2014;41(11):7543-53.

14. Pandurangan M, Hwang I. Application of cell co-culture system to study fat and muscle cells. Appl Microbiol Biotechnol. 2014;98(17):7359-64.

15. Cui HX, Guo LP, Zhao GP, Liu RR, Li QH, Zheng MQ, Wen J. Method using a co-culture system with high-purity intramuscular preadipocytes and satellite cells from chicken pectoralis major muscle. Poult Sci. 2018;97:3691-7.

16. Zhao Q, Kang Y, Wang HY, Guan WJ, Li XC, Jiang L, He XH, Pu YB, Han JL, $\mathrm{Ma} Y \mathrm{YH}$, et al. Expression profiling and functional characterization of miR-192 throughout sheep skeletal muscle development. Sci Rep. 2016;6:30281.

17. Huang HY, Zhang WT, Jiang WY, Chen SZ, Liu Y, Ge X, Li X, Dang YJ, Wen B, Liu XH, et al. RhoGDlbeta inhibits bone morphogenetic protein 4 (BMP4)induced adipocyte lineage commitment and favors smooth muscle-like cell differentiation. J Biol Chem. 2015;290(17):11119-29.

18. Quinn LS, Strait-Bodey L, Anderson BG, Argiles JM, Havel PJ. Interleukin-15 stimulates adiponectin secretion by 3T3-L1 adipocytes: evidence for a skeletal muscle-to-fat signaling pathway. Cell Biol Int. 2005;29(6):449-57.

19. Bolger AM, Lohse M, Usadel B. Trimmomatic: a flexible trimmer for Illumina sequence data. Bioinformatics. 2014;30(15):2114-20.

20. Huang d W, Sherman BT, Lempicki RA. Systematic and integrative analysis of large gene lists using DAVID bioinformatics resources. Nat Protoc. 2009; 4(1):44-57.

21. Livak KJ, Schmittgen TD. Analysis of relative gene expression data using real-time quantitative PCR and the 2(-Delta Delta C(T)) method. Methods. 2001;25(4):402-8.

22. Knight JD, Kothary R. The myogenic kinome: protein kinases critical to mammalian skeletal myogenesis. Skelet Muscle. 2011;1:29.

23. Zhang Q, Sun X, Xiao X, Zheng J, Li M, Yu M, Ping F, Wang Z, Qi C, Wang T, et al. Effects of maternal chromium restriction on the long-term programming in MAPK signaling pathway of lipid metabolism in mice. Nutrients. 2016;8(8). https://doi.org/10.3390/nu8080488.

24. Wang T, Takikawa Y, Tabuchi T, Satoh T, Kosaka K, Suzuki K. Carnosic acid (CA) prevents lipid accumulation in hepatocytes through the EGFR/MAPK pathway. J Gastroenterol. 2012;47(7):805-13.

25. Liu R, Wang H, Liu J, Wang J, Zheng M, Tan X, Xing S, Cui H, Li Q, Zhao G, et al. Uncovering the embryonic development-related proteome and metabolome signatures in breast muscle and intramuscular fat of fast-and slow-growing chickens. BMC Genomics. 2017;18(1):816.

26. Araya R, Riquelme MA, Brandan E, Saez JC. The formation of skeletal muscle myotubes requires functional membrane receptors activated by extracellular ATP. Brain Res Brain Res Rev. 2004;47(1-3):174-88.

27. Bentzinger CF, Wang YX, Rudnicki MA. Building muscle: molecular regulation of myogenesis. Cold Spring Harb Perspect Biol. 2012;4(2). https:// doi.org/10.1101/cshperspect.a008342.

28. Yang Q, Li Y, Zhang X, Chen D. Zac1/GPR39 phosphorylating CaMK-II contributes to the distinct roles of $\mathrm{Pax} 3$ and $\mathrm{Pax} 7$ in myogenic progression. Biochim Biophys Acta. 2018;1864(2):407-19.

29. Zammit PS. Function of the myogenic regulatory factors Myf5, MyoD, Myogenin and MRF4 in skeletal muscle, satellite cells and regenerative myogenesis. Semin Cell Dev Biol. 2017;72:19-32.

30. Hernandez-Hernandez JM, Garcia-Gonzalez EG, Brun CE, Rudnicki MA. The myogenic regulatory factors, determinants of muscle development, cell identity and regeneration. Semin Cell Dev Biol. 2017;72:10-8.

31. Hirai H, Verma M, Watanabe S, Tastad C, Asakura Y, Asakura A. MyoD regulates apoptosis of myoblasts through microRNA-mediated downregulation of Pax3. J Cell Biol. 2010;191(2):347-65.

32. Du C, Jin YQ, Qi JJ, Ji ZX, Li SY, An GS, Jia HT, Ni JH. Effects of myogenin on expression of late muscle genes through MyoD-dependent chromatin remodeling ability of myogenin. Mol Cells. 2012;34(2):133-42.

33. Rudnicki MA, Jaenisch $R$. The MYOD family of transcription factors and skeletal Myogenesis. Bioessays. 1995;17(3):203-9.

34. Seale P, Sabourin LA, Girgis-Gabardo A, Ahmed M, Gruss P, Rudnicki MA. Pax7 is required for the specification of myogenic satellite cells. Cell (Cambridge). 2000;102(6):777-86.

35. Millay DP, Gamage DG, Quinn ME, Min YL, Mitani Y, Bassel-Duby R, Olson EN. Structure-function analysis of myomaker domains required for myoblast fusion. Proc Natl Acad Sci U S A. 2016;113(8):2116-21.
36. Gamage DG, Leikina E, Quinn ME, Ratinov A, Chernomordik LV, Millay DP. Insights into the localization and function of myomaker during myoblast fusion. J Biol Chem. 2017;292(42):17272-89.

37. Millay DP, O'Rourke JR, Sutherland LB, Bezprozvannaya S, Shelton JM, BasselDuby R, Olson EN. Myomaker is a membrane activator of myoblast fusion and muscle formation. Nature. 2013:499(7458):301-5.

38. Luo W, Li E, Nie Q, Zhang X. Myomaker, regulated by MYOD, MYOG and miR140-3p, promotes chicken myoblast fusion. Int J Mol Sci. 2015;16(11):26186-201.

39. Xie S-J, Li J-H, Chen H-F, Tan Y-Y, Liu S-R, Zhang Y, Xu H, Yang J-H, Liu S, Zheng $L-L$, et al. Inhibition of the JNKMMAPK signaling pathway by myogenesis-associated miRNAs is required for skeletal muscle development Cell Death Differ. 2018. https://doi.org/10.1038/s41418-018-0063-1.

40. Wilfling F, Haas JT, Walther TC, Farese RV Jr. Lipid droplet biogenesis. Curr Opin Cell Biol. 2014;29:39-45.

41. Wang ZX, Li QG, Chamba Y, Zhang B, Shang P, Zhang H, Wu CX. Identification of genes related to growth and lipid deposition from transcriptome profiles of pig muscle tissue. PLoS One. 2015;10(10):e0141138.

42. Guo J, Shu G, Zhou L, Zhu X, Liao W, Wang S, Yang J, Zhou G, Xi Q, Gao P, et al. Selective transport of long-chain fatty acids by FAT/CD36 in skeletal muscle of broilers. Animal. 2013;7(3):422-9.

43. Furuhashi M, Hotamisligil GS. Fatty acid-binding proteins: role in metabolic diseases and potential as drug targets. Nat Rev Drug Discov. 2008;7(6):489-503.

44. Bowman TA, O'Keeffe KR, D'Aquila T, Yan QW, Griffin JD, Killion EA, Salter DM, Mashek DG, Buhman KK, Greenberg AS. Acyl CoA synthetase 5 (ACSL5) ablation in mice increases energy expenditure and insulin sensitivity and delays fat absorption. Mol Metab. 2016;5(3):210-20.

45. Zikova M, Corlett A, Bendova Z, Pajer P, Bartunek P. DISP3, a sterol-sensing domain-containing protein that links thyroid hormone action and cholesterol metabolism. Mol Endocrinol (Baltimore, MD). 2009;23(4):520-8.

46. Bosma M, Hesselink MK, Sparks LM, Timmers S, Ferraz MJ, Mattijssen F, van Beurden D, Schaart G, de Baets MH, Verheyen FK, et al. Perilipin 2 improves insulin sensitivity in skeletal muscle despite elevated intramuscular lipid levels. Diabetes. 2012;61(11):2679-90.

47. Feng YZ, Lund J, Li Y, Knabenes IK, Bakke SS, Kase ET, Lee YK, Kimmel AR, Thoresen GH, Rustan AC, et al. Loss of perilipin 2 in cultured myotubes enhances lipolysis and redirects the metabolic energy balance from glucose oxidation towards fatty acid oxidation. J Lipid Res. 2017;58(11):2147-61.

48. MacPherson RE, Ramos SV, Vandenboom R, Roy BD, Peters SJ. Skeletal muscle PLIN proteins, ATGL and CGI-58, interactions at rest and following stimulated contraction. Am J Physiol Regul, Integr Comp Physiol. 2013; 304(8):R644-50.

49. Shen Y, Zhao Y, Zheng D, Chang X, Ju S, Guo L. Effects of orexin a on GLUT4 expression and lipid content via MAPK signaling in 3T3-L1 adipocytes. J Steroid Biochem Mol Biol. 2013;138:376-83.

50. Gubern A, Barcelo-Torns M, Barneda D, Lopez JM, Masgrau R, Picatoste F, Chalfant CE, Balsinde J, Balboa MA, Claro E. JNK and ceramide kinase govern the biogenesis of lipid droplets through activation of group IVA phospholipase A2. J Biol Chem. 2009;284(47):32359-69.

51. Moreno M, Lombardi A, Silvestri E, Senese R, Cioffi F, Goglia F, Lanni A, de Lange P. PPARs: nuclear receptors controlled by, and controlling, nutrient handling through nuclear and cytosolic signaling. PPAR Res. 2010;2010. https://doi.org/10.1155/2010/435689.

52. Cui HX, Liu RR, Zhao GP, Zheng MQ, Chen JL, Wen J. Identification of differentially expressed genes and pathways for intramuscular fat deposition in pectoralis major tissues of fast-and slow-growing chickens. BMC Genomics. 2012;13:213.

53. Ciobanasu C, Faivre B, Le Clainche C. Integrating actin dynamics, mechanotransduction and integrin activation: the multiple functions of actin binding proteins in focal adhesions. Eur J Cell Biol. 2013;92(10-11): 339-48.

54. Huttenlocher A, Horwitz AR. Integrins in cell migration. Cold Spring Harb Perspect Biol. 2011;3(9):a005074.

55. Yu H, Lui YS, Xiong S, Leong WS, Wen F, Nurkahfianto H, Rana S, Leong DT, $\mathrm{Ng} \mathrm{KW}$, Tan LP. Insights into the role of focal adhesion modulation in myogenic differentiation of human mesenchymal stem cells. Stem Cells Dev. 2013;22(1):136-47.

56. Malone CM, Domaschenz R, Amagase Y, Dunham I, Murai K, Jones PH. Hes6 is required for actin cytoskeletal organization in differentiating $\mathrm{C}_{2} \mathrm{C} 12$ myoblasts. Exp Cell Res. 2011;317(11):1590-602.

57. Graham ZA, Gallagher PM, Cardozo CP. Focal adhesion kinase and its role in skeletal muscle. J Muscle Res Cell Motil. 2015;36(4-5):305-15. 
58. Nobusue H, Onishi N, Shimizu T, Sugihara E, Oki Y, Sumikawa Y, Chiyoda T, Akashi K, Saya H, Kano K. Regulation of MKL1 via actin cytoskeleton dynamics drives adipocyte differentiation. Nat Commun. 2014;5:3368.

59. Lee HJ, Jang M, Kim H, Kwak W, Park W, Hwang JY, Lee CK, Jang GW, Park MN, Kim HC, et al. Comparative transcriptome analysis of adipose tissues reveals that ECM-receptor interaction is involved in the depot-specific Adipogenesis in cattle. PLoS One. 2013;8(6):e66267.

60. Weibel GL, Joshi MR, Jerome WG, Bates SR, Yu KJ, Phillips MC, Rothblat GH. Cytoskeleton disruption in $\mathrm{J774}$ macrophages: consequences for lipid droplet formation and cholesterol flux. Biochim Biophys Acta Mol Cell Biol Lipids. 2012;1821(3):464-72.

61. Priyadarshini E, Anuradha CV. Glucocorticoid antagonism reduces insulin resistance and associated lipid abnormalities in high-fructose-fed mice. Can J Diabetes. 2017;41(1):41-51.

62. Lee HY, Lee JS, Alves T, Ladiges W, Rabinovitch PS, Jurczak MJ, Choi CS, Shulman GI, Samuel VT. Mitochondrial-targeted catalase protects against high-fat diet-induced muscle insulin resistance by decreasing intramuscular lipid accumulation. Diabetes. 2017;66(8):2072-81.

63. Wolf P, Winhofer Y, Anderwald CH, Krssak M, Krebs M. Intracellular lipid accumulation and shift during diabetes progression. Wien Med Wochenschr (1946). 2014;164(15-16):320-9.

Ready to submit your research? Choose BMC and benefit from:

- fast, convenient online submission

- thorough peer review by experienced researchers in your field

- rapid publication on acceptance

- support for research data, including large and complex data types

- gold Open Access which fosters wider collaboration and increased citations

- maximum visibility for your research: over $100 \mathrm{M}$ website views per year

At $\mathrm{BMC}$, research is always in progress.

Learn more biomedcentral.com/submissions 